\title{
The Influence of the Tillage System and Fertilization on Soybean Yield at ARDS Turda, 2015-2017
}

\author{
Alina ŞIMON*, Felicia CHEŢAN, Cornel CHEŢAN, Marius BĂRDAŞ, Valeria DEAC \\ Agricultural Research-Development Station Turda, 25 Agricultirii St., Turda, România \\ *corresponding author: maralys84@yahoo.com
}

Bulletin UASVM series Agriculture 76(2) / 2019

Print ISSN 1843-5246; Electronic ISSN 1843-5386

DOI:10.15835/buasvmcn-agr: 2018.0030

\begin{abstract}
Soybean is currently one of the most important agricultural crops being used in human and animal nutrition, as a raw material for industry but also has agro-phyto-technical importance because it contributes to the raising of soil fertility by fixing atmospheric nitrogen by symbiosis between soybeans and Rhizobium japonicum bacteria, which forms root-nodules. To achieve the aims, a poly-factorial experience has been placed during the period 20152017 at ARDS Turda, with the factors: Factor $\mathrm{A}$ - the tillage system $\left(\mathrm{a}_{1}\right.$ the classical tillage system by plowing with the return of the furrow and $\mathrm{a}_{2}$ the minimum tillage system, chisel variant; factor $\mathrm{B}$ - the fertilization $\left(\mathrm{b}_{1}-\mathrm{N}_{20} \mathrm{P}_{20} \mathrm{~K}_{0}\right.$ $100 \mathrm{~kg} / \mathrm{ha}$, applied simultaneously with sowing, $\mathrm{b}_{2}-\mathrm{N}_{20} \mathrm{P}_{20} \mathrm{~K}_{0} 100 \mathrm{~kg} / \mathrm{ha}$, applied simultaneously with the sowing $+\mathrm{N}_{20} \mathrm{P}_{20} \mathrm{~K}_{0} 100 \mathrm{~kg} / \mathrm{ha}$, applied in the 4-6 leaves phenophase, $\mathrm{b}_{3}-\mathrm{N}_{20} \mathrm{P}_{20} \mathrm{~K}_{0} 100 \mathrm{~kg} / \mathrm{ha}$ applied simultaneously with sowing $+\mathrm{N}_{30} 100 \mathrm{~kg} / \mathrm{ha}$, applied in the 4-6 leaves phenophase and $\mathrm{b}_{4}-\mathrm{N}_{20} \mathrm{P}_{20} \mathrm{~K}_{0} 100 \mathrm{~kg} / \mathrm{ha}$ applied simultaneously with sowing $+\mathrm{N}_{20} 100 \mathrm{~kg} / \mathrm{ha}$, applied in the 4-6 leaves phenophase, factor C-climatic conditions in the experimental years $\left(c_{1}-2015 ; c_{2}-2016 ; c_{3}-2017\right)$. The soybean variety studied was Malina TD. Following the application of the minimum tillage system, the yield decreases with a significant difference of $86 \mathrm{~kg} / \mathrm{ha}$ compared to the conventional tillage system. A very significant influence in the yield of superior quantitative yields is fertilization, in the three variants where the supplementary fertilization was applied, there were obtained very significant yield increases of over $199 \mathrm{~kg} / \mathrm{ha}$ compared to the control variant which produced a yield of $2373 \mathrm{~kg} / \mathrm{ha}$.
\end{abstract}

Keywords: tillage system, soybean, climatic conditions, fertilization, yield

\section{Introduction}

It is known that in recent years the climate has undergone major changes, increasing the average annual temperature and the lack or unevenness of precipitation being the most important factors influencing the production of a culture (Şimon and Ignea, 2018). In order to reduce the impact of these changes on crops, researchers from all over the world have sought for the most efficient technological alternatives to produce quantitatively and qualitatively yields in line with plant needs and current climate change (Szajdak et al., 2003; Simon et al., 2014). The main directions in which research has been carried out and which have achieved results with applicability have been the implementation of conservative tillage systems that have evolved over time (Guş et al., 2003), the reduction of imputations by rotation of zoned varieties and the introduction of leguminous into crops.

Soybean (Glycinemax (L.) Merrill) is considered to be the "golden plant" of mankind, the "wonder plant" or the "plant of the future" (Singh, 2010), a culture of special nutritional value for both human nutrition and animals fodder, being the main source of plant protein worldwide (Conner et al., 2004). In addition to the importance of food, soybean also contributes to the improvement of soil fertility by fixing the atmospheric nitrogen by symbiosis between soybeans and Rhizobium japonicum bacteria, which forms root-nodules (Roman et al., 2006). The increase in nitrate content of $\mathrm{NO}_{3}^{-}$ 
or ammonium $\mathrm{NH}_{4}{ }^{+}$in the soil has the effect of decreasing the activity of the nodules formation, being correlated with a decrease of the nodules formation capacity of the leguminous species (Eaglesham, 1989), but analyzed in complex with the soil tillage system, phase fertilization is necessary, giving a distinctly significant yield increase compared to the conventional system of works (Chețan et al., 2014).

The rise and development of soybeans are influenced by soil temperature and humidity (Hunter and Erickson, 1952), and the implementation of conservative tillage systems, whose characteristics include increasing or maintaining water for a long time in the soil, can lead to a more efficient use of precipitation water in the processes of germination, growth and development of plants.

The purpose of this paper is to study the influence of fertilization of soybean culture on the number of nodules that are formed and yield obtained.

\section{Materials and methods}

The experiment was conducted between 20152017 at Agricultural Research and Development Station Turda (ARDS Turda), on a faeozem vertical soil with neutral $\mathrm{pH}$, loam-clay texture, humus medium content, good phosphorus and potassium supply.

The soybean was sown with a distance of 18 $\mathrm{cm}$, with the Gaspardo Directa 400 seed drill at 65 g.s. $/ \mathrm{m}^{2}$. The soybean has been grown in a crop rotation system for 3 years, the pre-plant being maize.

Factor A - the tillage system: $\mathrm{a}_{1}$ - The classical tillage system, which includes a $30 \mathrm{~cm}$ deep, hole after harvesting the previous crop and soil processing to prepare the germinating bed with the disc and combiner before sowing; $\mathrm{a}_{2}$ - Minimum tillage system with the chisel at $30 \mathrm{~cm}$ deep, after harvesting the previous crop and soil processing to prepare the germinating bed with the rotary before sowing; factor B- the fertilization $\left(\mathrm{b}_{1}-\mathrm{N}_{20} \mathrm{P}_{20} \mathrm{~K}_{0} 100\right.$ $\mathrm{kg} / \mathrm{ha}$, applied simultaneously with sowing, $\mathrm{b}_{2}$ $\mathrm{N}_{20} \mathrm{P}_{20} \mathrm{~K}_{0} 100 \mathrm{~kg} / \mathrm{ha}$, applied simultaneously with the sowing $+\mathrm{N}_{20} \mathrm{P}_{20} \mathrm{~K}_{0} 100 \mathrm{~kg} / \mathrm{ha}$, applied in the 4-6 leaves phenophase, $b_{3}-N_{20} P_{20} K_{0} 100 \mathrm{~kg} / \mathrm{ha}$ applied simultaneously with sowing $+\mathrm{N}_{30} 100 \mathrm{~kg} /$ ha, applied in the 4-6 leaves phenophase and $b_{4}$ $\mathrm{N}_{20} \mathrm{P}_{20} \mathrm{~K}_{0} 100 \mathrm{~kg} / \mathrm{ha}$ applied simultaneously with sowing $+\mathrm{N}_{20} 100 \mathrm{~kg} / \mathrm{ha}$, applied in the 4-6 leaves phenophase, factor C-climatic conditions in the experimental years $\left(c_{1}-2015 ; c_{2}-2016 ; c_{3}-2017\right)$. The soybean variety studied was Mălina TD.

After sowing, treatment with Gliphosate (glifosat 360g/l) (4 l/ha) was performed in the two systems. Control of monocotyledonous and dicotyledonous weeds was performed with Pulsar herbicides (imazamox 40g/l) (1 l/ha) and Agil (propaquizafop) (1 l/ha) in weed rosette phenophase.

To protect the soybean culture against the red spider (Tetranicus urticae), the Omite 570 EW (propargit $570 \mathrm{~g} / \mathrm{l})(0,8 \mathrm{l} / \mathrm{ha})$ insecticide treatment was performed and with the Ridomil Gold MZ 68 WG (mancozeb $40 \mathrm{~g} / \mathrm{kg}$, mefenoxam $680 \mathrm{~g} / \mathrm{kg})(2,5 \mathrm{~kg} / \mathrm{ha})$ fungicide was treated the Peronospora manshurica.

The obtained results were statistically processed by the variance analysis method and the lowest significant difference was determined DL - (5\%, 1\% and 0.1\%) (ANOVA, 2015).

The climate conditions during 2015-2017 are presented according to ARDS Turda Meteo Station (Tab. 1 and Tab. 2). During the last 60 years, the annual temperature average recorded was $9.1^{\circ} \mathrm{C}$ and the annual amount of rainfall was $531.0 \mathrm{~mm}$. The average temperatures recorded during the months from the vegetation period of soybean crop have varied during all three years, but they were higher than the average during 60 years by $1.5^{\circ} \mathrm{C}$ in 2015 , being considered a hot year, by $0.9^{\circ} \mathrm{C}$ in 2016 , being considered a warm year and by $1.4^{\circ} \mathrm{C}$ in 2017 , considered a hot year.

The amount of rainfall recorded in the first half of 2015 was under the monthly amount during the last 60 years, in 2016 the amount of rainfall was higher than the average during 60 years, being considered an excessively rainy year. In 2015 , the rainfall was more reduced, and its absence during the optimal moments for the development of the crop resulted in a significant production loss. In 2016, temperatures and rainfall were beneficial for the soybean crop, the yield obtained were the result of the interaction between optimal climate conditions. In 2017, the rainfall were close to the average of the past 60 years.

\section{Results and discussions}

Soybean yield varies from one crop to another, but yield stability is influenced by several factors, 
Table 1. The mean air temperatures $\left({ }^{\circ} \mathrm{C}\right)$, Turda $2015-2017$

\begin{tabular}{|c|c|c|c|c|c|c|c|c|c|c|c|c|}
\hline \multirow{3}{*}{$\begin{array}{l}\text { Monthly } \\
\text { average }\end{array}$} & \multicolumn{12}{|c|}{2015} \\
\hline & Ian. & Feb. & Mar. & Apr. & May & Jun. & Jul. & Aug. & Sep. & Oct. & Nov. & Dec. \\
\hline & -0.7 & 0.0 & 5.5 & 9.6 & 15.8 & 19.4 & 22.3 & 21.9 & 17.3 & 9.7 & 6.1 & 0.7 \\
\hline $\begin{array}{c}\text { Average } 60 \\
\text { years }\end{array}$ & -3.4 & -0.9 & 4.7 & 9.9 & 15.0 & 17.9 & 19.7 & 19.3 & 15.1 & 9.5 & 3.9 & -1.4 \\
\hline Deviation & +2.7 & +0.9 & +1.2 & -0.3 & +0.8 & +1.5 & +2.6 & +2.6 & +2.2 & +0.2 & +2.2 & +2.3 \\
\hline \multicolumn{13}{|c|}{2016} \\
\hline \multirow{2}{*}{$\begin{array}{l}\text { Monthly } \\
\text { average }\end{array}$} & Ian. & Feb. & Mar. & Apr. & May & Jun. & Jul. & Aug. & Sep. & Oct. & Nov. & Dec. \\
\hline & -2.8 & 4.6 & 5.9 & 12.4 & 14.3 & 19.8 & 20.5 & 19.6 & 17.1 & 8.3 & 2.9 & -2.7 \\
\hline $\begin{array}{c}\text { Average } 60 \\
\text { years }\end{array}$ & -3.4 & -0.9 & 4.7 & 9.9 & 15.0 & 17.9 & 19.7 & 19.3 & 15.1 & 9.5 & 3.9 & -1.4 \\
\hline Deviation & +0.6 & +5.5 & +1.2 & +2.5 & -0.7 & +1.9 & +0.8 & +0.3 & +2.0 & -1.2 & -1.0 & -1.3 \\
\hline \multicolumn{13}{|c|}{2017} \\
\hline \multirow[t]{2}{*}{$\begin{array}{l}\text { Monthly } \\
\text { average }\end{array}$} & Ian. & Feb. & Mar. & Apr. & May & Jun. & Jul. & Aug. & Sep. & Oct. & Nov. & Dec. \\
\hline & -6.7 & 1.5 & 8.4 & 9.9 & 15.7 & 20.7 & 20.3 & 22.3 & 15.8 & 11.6 & 4.9 & 1.0 \\
\hline $\begin{array}{c}\text { Average } 60 \\
\text { years }\end{array}$ & -3.4 & -0.9 & 4.7 & 9.9 & 15.0 & 17.9 & 19.7 & 19.3 & 15.1 & 9.5 & 3.9 & -1.4 \\
\hline Deviation & -3.3 & +2.4 & +3.7 & 0.0 & +0.7 & +2.8 & +0.6 & +3.0 & +0.7 & +2.1 & +1.0 & +2.4 \\
\hline
\end{tabular}

Table 2. Recorded precipitation (mm), Turda 2015-2017

\begin{tabular}{|c|c|c|c|c|c|c|c|c|c|c|c|c|}
\hline \multirow{3}{*}{$\begin{array}{l}\text { Monthly } \\
\text { amount }\end{array}$} & \multicolumn{12}{|c|}{2015} \\
\hline & Ian. & Feb. & Mar. & Apr. & May & Jun. & Jul. & Aug. & Sep. & Oct. & Nov & Dec \\
\hline & 12.3 & 20.9 & 12.8 & 32.2 & 66.0 & 115.7 & 52.2 & 72.2 & 172.6 & 45.4 & 32.0 & 6.9 \\
\hline $\begin{array}{c}\text { Average } 60 \\
\text { years }\end{array}$ & 21.8 & 18.8 & 23.6 & 45.9 & 68.7 & 84.8 & 77.1 & 56.5 & 42.5 & 35.6 & 28.5 & 27.1 \\
\hline Deviation & -9.5 & +2.1 & -10.8 & -13.7 & -2.7 & +30.9 & -24.9 & +15.7 & +130.1 & +9.8 & +3.5 & -20.2 \\
\hline \multicolumn{13}{|c|}{2016} \\
\hline \multirow{2}{*}{$\begin{array}{l}\text { Monthly } \\
\text { amount }\end{array}$} & Ian. & Feb. & Mar. & Apr. & May & Jun. & Jul. & Aug. & Sep. & Oct. & Nov & Dec \\
\hline & 25.0 & 23.8 & 47.0 & 62.2 & 90.4 & 123.2 & 124.9 & 91.0 & 24.6 & 152.2 & 45.3 & 7.2 \\
\hline $\begin{array}{c}\text { Average } 60 \\
\text { years }\end{array}$ & 21.8 & 18.8 & 23.6 & 45.9 & 68.7 & 84.8 & 77.1 & 56.5 & 42.5 & 35.6 & 28.5 & 27.1 \\
\hline Deviation & +4.2 & +5.0 & +23.4 & +16.3 & +21.7 & +38.4 & +47.8 & +34.5 & -17.9 & +116.6 & +16.8 & -19.9 \\
\hline \multicolumn{13}{|c|}{2017} \\
\hline \multirow{2}{*}{$\begin{array}{l}\text { Monthly } \\
\text { amount }\end{array}$} & Ian. & Feb. & Mar. & Apr. & May & Jun. & Jul. & Aug. & Sep. & Oct. & Nov & Dec. \\
\hline & 2.6 & 19.2 & 46.1 & 65.2 & 65.4 & 30.6 & 110.2 & 36.1 & 56.2 & 49.2 & 30.8 & 20.7 \\
\hline $\begin{array}{c}\text { Average } 60 \\
\text { years }\end{array}$ & 21.8 & 18.8 & 23.6 & 45.9 & 68.7 & 84.8 & 77.1 & 56.5 & 42.5 & 35.6 & 28.5 & 27.1 \\
\hline Deviation & -19.2 & +0.4 & +25.5 & +19.3 & -3.3 & -54.2 & +33.1 & -20.5 & +13.7 & +13.6 & +2.3 & -6.4 \\
\hline
\end{tabular}

the most important being climatic conditions, soil fertility, crop protection against diseases, weeds and pests, and tillage. The suitability of a crop to tillage by a particular method is dependent on the soil type, texture, structure and water retention capacity of the soil. From the data presented in Tab. 3 it can be noticed that the yield obtained from the application of the conservative tillage system is lower than the yield obtained in the classical tillage system, with a distinct difference of $86 \mathrm{~kg} / \mathrm{ha}$. The results obtained by Chețan et al.
(2016) also shows that soybean yield obtained on the same soil type is lower due to the application of the conservative tillage system, with very significant differences from the classical tillage system.

Although soybean is a plant that does not require a high level of nitrogen fertilization (thanks to the atmospheric nitrogen fixation due to symbiosis with Rhyzobium japonicum bacterium), it responds very well to the application of additional fertilization, especially those containing 
Table 3. The influence of the tillage system on the yield of soybean

\begin{tabular}{ccc}
\hline Tillage system & Yield (kg/ha) & Differences (kg/ha) \\
\hline Classic (control variant) & 2599 & - \\
\hline Conservative & $2513^{00}$ & -86 \\
\hline LSD (p 5\%) 19 & LSD (p 1\%) 49 & LSD (p 0.1\%) 140 \\
\hline
\end{tabular}

Table 4. The influence of the fertilization on the yield of soybean

\begin{tabular}{ccc}
\hline Fertilization & Yield (kg/ha) & Differences (kg/ha) \\
\hline $\mathrm{N}_{20} \mathrm{P}_{20} \mathrm{~K}_{0}$-simultaneously with sowing (control variant) & 2373 & - \\
\hline $\mathrm{N}_{20} \mathrm{P}_{20} \mathrm{~K}_{0}$-simultaneously with sowing+ $\mathrm{N}_{20} \mathrm{P}_{20} \mathrm{~K}_{0}$-in the 4-6 leaves & $2678^{* * *}$ & 305 \\
\hline $\mathrm{N}_{20} \mathrm{P}_{20} \mathrm{~K}_{0}$-simultaneously with sowing+ $\mathrm{N}_{30}$-in the 4-6 leaves & $2601^{* * *}$ & 228 \\
\hline $\mathrm{N}_{20} \mathrm{P}_{20} \mathrm{~K}_{0}$-simultaneously with sowing+ $\mathrm{N}_{20}$-in the 4-6 leaves & $2571^{* * *}$ & 199 \\
\hline LSD (p 5\%) 17 & LSD (p 1\%) 26 & LSD (p 0.1\%) 42 \\
\hline
\end{tabular}

Table 5. The influence of the year factor on the yield of soybean

\begin{tabular}{ccc}
\hline Tillage system & Yield (kg/ha) & Differences (kg/ha) \\
\hline Average year (control variant) & 2556 & - \\
\hline 2015 & $2057^{000}$ & -499 \\
\hline 2016 & $3429^{* * *}$ & 873 \\
\hline 2017 & $2182^{000}$ & -374 \\
\hline LSD (p 5\%) 16 & LSD (p 1\%) 39 & LSD (p 0.1\%) 112 \\
\hline
\end{tabular}

Table 6. The influence of the tillage system on the number of root nodules

\begin{tabular}{ccc}
\hline Tillage system & Root nodules & Differences \\
\hline Classic (control variant) & 324 & - \\
\hline Conservative & $354^{*}$ & 30 \\
\hline LSD (p 5\%) 7 & LSD (p 1\%) 38 & LSD (p 0.1\%) 135 \\
\hline
\end{tabular}

phosphorus, from the data presented in Tab.4 shows an increase with very significant positive differences in yield in all three variants where additional fertilization was applied, especially in the second variant where the application of $100 \mathrm{~kg} / \mathrm{ha}$ of $\mathrm{N}_{20} \mathrm{P}_{20}$ resulted in an yield increase over $305 \mathrm{~kg} / \mathrm{ha}$. The results obtained by Chețan et al., (2017) confirm the data presented by the yield obtained following application of additional fertilization to the soybean cultivated under similar conditions.

The yield of soybean culture is determined by the weight and number of seeds. The seed weight is a production item influenced by the duration of the actual grain filling period, and the number is determined by the duration of the flowering period, which requires average temperatures (to avoid abortion of the flowers) and quantitative precipitation, this period from the beginning of the flowering and until grain filling is critical to soybean culture. In 2016, when the rainfall in the important phases of the vegetation period was above the average of 60 years, the registered soybean yield was $3429 \mathrm{~kg} / \mathrm{ha}$, with a significantly higher difference than the average of the years 2015-2017, while in the other two years the yields were relatively lower, of only $2057 \mathrm{~kg} / \mathrm{ha}$ in 2015 and respectively $2182 \mathrm{~kg} / \mathrm{ha}$ in 2017, the yield differences from the average of the three studied years being significantly lower (Tab. 5).

Soil tillage has complex effects on the physical, chemical and biological properties of the soil, and the change of these soil properties directly influences the parameters of microbial activity in soil, organic matter, soil humidity and temperature.

The development of the soybean plant is influenced by the nutritional state of the crop, climatic conditions, genotype and nutrition space, but the development of roots and, implicitly, the number, size and weight of the root nodules 
Table 7. The influence of the fertilization on the number of root nodules

\begin{tabular}{ccc}
\hline Fertilization & Root nodules & Differences \\
\hline $\mathrm{N}_{20} \mathrm{P}_{20} \mathrm{~K}_{0}$-simultaneously with sowing (control variant) & 270 & - \\
\hline $\mathrm{N}_{20} \mathrm{P}_{20} \mathrm{~K}_{0}$-simultaneously with sowing+ $\mathrm{N}_{20} \mathrm{P}_{20} \mathrm{~K}_{0}$-in the 4-6 leaves & $291^{*}$ & 21 \\
\hline $\mathrm{N}_{20} \mathrm{P}_{20} \mathrm{~K}_{0}$-simultaneously with sowing+ $\mathrm{N}_{30}$-in the 4-6 leaves & $259^{0}$ & -11 \\
\hline $\mathrm{N}_{20} \mathrm{P}_{20} \mathrm{~K}_{0}$-simultaneously with sowing $+\mathrm{N}_{20}$-in the 4-6 leaves & $262^{0}$ & -8 \\
\hline LSD (p 5\%) 8 & LSD (p 1\%) 23 & LSD (p 0.1\%) 40 \\
\hline
\end{tabular}

Table 8. The influence of the year factor on the number of root nodules

\begin{tabular}{ccc}
\hline Tillage system & Root nodules & Differences \\
\hline Average year (control variant) & 289 & - \\
\hline 2015 & $273^{0}$ & -16 \\
\hline 2016 & $314^{* *}$ & 24 \\
\hline 2017 & $281^{0}$ & -8 \\
\hline LSD (p 5\%) 6 & LSD (p 1\%) 19 & LSD (p 0.1\%) 32 \\
\hline
\end{tabular}

developed on the roots of plants is the result of physical properties and the way tillage. According to the data presented in Tab. 6, the number of root nodules on soybean roots is higher in the system with conservative tillage, with a significant difference from the control, similar studies have resulted in the conservative tillage system having positive effects on the soil microbial activity.

The root system of soybean plants cultivated in the classical tillage system is better developed than in the conservative system, but the number of root nodules determined on the roots of plants is higher in the conservative system, their layout being on the main roots compared to the ones determined in the classical system that were arranged on both the main and the secondary roots.

Mineral fertilization of soybean culture with nitrogen leads to a decrease in the number of root nodules, but in the case of phosphorus-containing fertilizers, the number of root nodules is higher, phosphorus stimulating their development. The activity of developing and fixing nitrogen by the root nodules is suppressed when the nodules roots are exposed to a high nitrogen concentration. As can be seen from the data presented in Tab. 7, the number of root nodules decreases with significant differences due to the application of additional mineral fertilization with nitrogen, and after application of phosphorus mineral fertilization the number of root nodules on the roots of the plants increases with a significant difference compared to the basic fertilization applied simultaneously with sowing. When the availability of nitrogen is low in the soil, the plant preferentially supports root nodules growth and nitrogen fixation, on the other hand when the nitrate level in the soil is high, the plant stimulates lateral growth of the roots to absorb nitrates more efficiently (Saito et al., 2014).

Natural soil fertility, especially phosphorus content in the soil, is an important factor contributing to the formation of root nodules resulting from the symbiosis process between soybean roots and Rhizobium japonicum nitrogen fixation bacteria. In the experiments performed by Pavanelli and Araújo (2009) there was a low soy nodulation, a decrease attributable to the low level of fertility of the soil.

Climate conditions are the most important factor in the development of a crop, soil temperature being very important during the formation of nodosites on the roots of soybean plants, which contributes to the assimilation of atmospheric nitrogen, temperatures too low or too high, preventing their good development $\left(<20^{\circ}\right.$ and $\left.>30^{\circ} \mathrm{C}\right)$, temperatures close to $25^{\circ} \mathrm{C}$ are optimal for the bacteria activation and symbiotic process between bacteria and soybean roots, favoring the increase in the amount of nitrogen assimilated and transformed into available plant nitrogen.

The data presented in Tab. 8 shows that in 2016 recorded temperatures and precipitations have reached optimal conditions for the formation and development of soybean root nodules, thus the number of root nodules is higher than the number obtained by calculating the average of the 
three years with a dinstinct significantly positive difference, and in the years 2015 and 2017, the lack of precipitation during the formation of the nodosities resulted in a significant decrease in the number of toor nodules formed on the root of a plant.

From the determinations made by Cheţan et al. (2016) shows that in the years favorable to the development of soybean culture, the number of root nodules is significantly higher than the control, fallen temperatures and precipitations favoring the formation of root nodules and the assimilation of atmospheric nitrogen.

\section{Conclusions}

The yield of a crop is determined by several factors that interfere with the physiological processes of a plant and which vary according to the interaction between these factors.

Additional fertilization of the soybean crop produces significant yield increases, but by applying nitrogen-based fertilization, the number of nitrogen-fixing root nodules on the roots of soybean plants is reduced.

The climatic conditions of the soybean crop growing season are the most important factor in the development of soybean root nodules and in the formation of yield.

Acknowledgements: This work was supported by a grant of the Romanian Ministery of Research and Innovation, CCCDI-UEFISCDI, project number PN-III-P1-1.2-PCCDI-2017-0056, within PNCDI III.

\section{References}

1. ANOVA (2015). PoliFact and Duncan's test pc program for variant analyses made for completely randomized polifactorial experiences. USAMV Cluj-Napoca, Romania.

2. Chețan F, Rusu T, Chețan C, Șimon A, Igne, M, Deac V. (2014). Rezultate de producție obținute la soia în sistemul cu lucrări minime ale solului în perioada 2007-2012, la SCDA Turda, AN. INCDA Fundulea, LXXXII: 215-226.

3. Chețan C, Rusu T, Chețan F, Șimon A (2016). Influence of soil tillage and weed control treatments on root nodules, production and qualitative indicators of soybean. Procedia Technology, 22:: 457-464.

4. Chețan C, Rusu T, Chețan F, Șimon, A (2016). Research Regarding the Influence of the Weed Control Treatments on Production and Qualitative Indicators of the Soybean Cultivated in Minimum Tillage System, Bulletin UASVM series Agriculture 73(2): 170-175.

5. Chețan F, Chețan C, Şimon A, Deac, V (2017). Influența sistemului de fertilizare și de lucrare a solului asupra conservării apei în sol și producției la cultura de soia la S.C.D.A. Turda, AN. I.N.C.D.A. Fundulea, LXXXV: 133-143.

6. Conner T, Paschal EH, Barbero A, Johnson E (2004). The challenges and potential for future agronomic traits in soybeans. AgBioForum, 7, (1\&2): 47-50.

7. Eaglesham ARJ (1989). Nitrate inhibition of root-nodule symbiosis in doubly rooted soybean plants. Crop Science, 29: 115-119.

8. Guş P, Rusu T, Bogdan I (2003). Sisteme convenţionale şi neconvenţionale de lucrare a solului, Editura Risoprint, Cluj-Napoca.

9. Hunter JR, Erickson AE (1952). Relation of seed germination to soil moisture tension. Agron. J., 44:107109.

10. Pavanelli LE, Araújo FF (2009). Fixação biológica de nitrogênio em soja em solos cultivados com pastagens e culturas anuais do oeste paulista. Bioscience Journal, Uberlândia, 25(1): 21-29.

11. Roman GV, Ion V, Epure LI (2006). Fitotehnie - Cereale și leguminoase pentru boabe. Editura Ceres, București.

12. Saito A, Tanabata S, Tanabata T, Tajima S, Ueno M, Ishikawa S, Ohtake N, Sueyoshi K, Ohyama T (2014). Effect of Nitrate on Nodule and Root Growth of Soybean (Glycine max (L.) Merr.), Int. J. Mol. Sci., 15: 4464-4480.

13. Singh G. (2010). The soybean: botany, production and uses. Oxfordshire: CAB International.

14. Szajdak L., Zyczynska-Baloniak I, Jaskulska R (2003). Impact of afforestation on the limitation of the spread of the pollutions in ground water and in soils. Polish Journal of Environmental Studies, 12(4): 453-459.

15. Şimon A, Chețan F, Chețan C, Ignea M, Deac V (2014). Results on the influence of density and fertilization on yield varieties of peas type afila, AN. INCDA Fundulea, LXXXII: 227-232;

16. Şimon A., Ignea M. (2018). Caracterizarea climatică a anului 2017. Agricultura Transilvană, Buletin informativ, nr. 28, Ed. SC ELADESIGN SRL Turda, 12-15.

17. Turda Meteo Station. 